10. Tsymbaliuk, I. O. \& Mishchanchuk, O. O. (2014). Osoblyvosti vyznachennia podatkovoho navantazhennia na rivni derzhavy ta rehionu [Features of the definition of the tax burden at the level of the state and the region], Visnyk Khmelnytskoho natsionalnoho universytetu. Ekonomichni nauky. - Bulletin of the Khmelnitsky National University. Economic Sciences, 3(2), 101-106. URL: http://nbuv.gov.ua/UJRN/Vchnu_ekon_2014_ $3 \% 282 \% 29 \_23$ [in Ukrainian].

11. Paying-Taxes 2018 (2018). World bank Group. URL: https://www.pwc.com/gx/en/paying-taxes/pdf/pwc_ paying_taxes_2018_full_report.pdf [in English].

12. Karlin M. I. (2014). Problemy rozvytku finansovoi systemy Ukrainy ta shliakhy yikh vyrishennia [Problems of the development of the financial system of Ukraine and the ways of their solution], Lutsk, 99-115.

Стаття надійшла до редакціїі 12.02.2019 р.

УдК 336.02

Вахновська Наталія, кандидат економічних наук, доцент, Луцький національний технічний університет; кафедра фінансів, банківської справи та страхування; м. Луцьк; ORCID ID 0000-0002-3057-7834; e-mail: vna2712@ukr.net

Пиріг Світлана, кандидат економічних наук, доцент, Луцький національний технічний університет; кафедра фінансів, банківської справи та страхування; м. Луцьк; ORCID ID 0000-0002-1205-9814; e-mail: sw41@ua.fm

https://doi.org/10.29038/2411-4014-2019-01-115-120

\title{
ФІСКАЛЬНА СКЛАДОВА МІСЦЕВИХ БЮДЖЕТІВ В КОНТЕКСТІ ФІНАНСОВОЇ ДЕЦЕНТРАЛІЗАЦІЇ
}

У статті досліджено фінансове забезпечення формування доходів місцевих бюджетів в контексті сталого соціально-економічного розвитку територій. Досліджено фіскальну політику в напрямку формування власних доходів місцевих бюджетів, основні джерела їх наповнення. Проаналізовано склад та структуру місцевих податків та зборів, визначено наслідки реформи територіальної організації влади та обгрунтовано значення фіскальної складової підвищення бюджетного потенціалу місцевого рівня. Виокремлено проблеми стягнення та підвищення ролі місцевих податків та зборів як інструмента формування власних доходів місцевих бюджетів. Обгрунтовано напрямки впливу органів місцевого самоврядування на розмір фіскальної складової місцевих бюджетів.

Ключові слова: місцевий бюджет, бюджетний потенціал, фіскальна політика, місцеві податки та збори.

Вахновская Наталия, кандидат экономических наук, доцент, Луцкий национальный технический университет кафедра финансов, банковского дела и страхования; г. Луцк; ORCID ID 0000-0002-3057-7834; e-mail: vna2712@ukr.net

Пыриг Светлана, кандидат экономических наук, доцент, Луцкий национальный технический университет кафедра финансов, банковского дела и страхования; г. Луцк; ORCID ID 0000-0002-1205-9814; e-mail: sw41@ua.fm

\section{ФИСКАЛЬНАЯ СОСТАВЛЯЮЩАЯ МЕСТНЫХ БЮДЖЕТОВ В КОНТЕКСТЕ ФИНАНСОВОЙ ДЕЦЕНТРАЛИЗАЦИИ}


В статье исследовано финансовое обеспечение формирования доходов местных бюджетов в контексте устойчивого социально-экономического развития территорий. Исследуется фискальная политика в направлении формирования собственных доходов местных бюджетов, основные источники их наполнения. Проанализированы состав и структура местных налогов и сборов, определены последствия реформы территориальной организации власти и обосновано значение фискальной составляющей повышения бюджетного потенциала местного уровня. Выделены проблемы взыскания и повышение роли местных налогов и сборов как инструмента формирования собственных доходов местных бюджетов. Обоснованы направления влияния органов местного самоуправления на размер фискальной составляющей местных бюджетов.

Ключевые слова: местный бюджет, бюджетный потенциал, фискальная политика, местные налоги и сборы.

\author{
Vakhnovska Nataliya, \\ PhD in Economics, Associate Professor, \\ Lutsk National Technical University, \\ Department of Finance, Banking and Insurance; \\ Lutsk; ORCID ID 0000-0002-3057-7834; \\ e-mail: vna2712@ukr.net \\ Pyrih Svitlana, \\ PhD in Economics, Associate Professor, \\ Lutsk National Technical University, \\ Department of Finance, Banking and Insurance; \\ Lutsk;ORCID ID 0000-0002-1205-9814; \\ e-mail: sw41@ua.fm
}

\title{
FISCAL COMPOSITION OF LOCAL BUDGETS IN THE CONTEXT OF FINANCIAL DECENTRALIZATION
}

The purpose of the article is to determine the role of the fiscal component of local budgets in the context of financial decentralization.

Sustainable development of the state and its regions is determined by the budget potential of a separate administrative-territorial unit, that is, the volume of own and attracted financial resources accumulated in the local budget. Internal fiscal potential is seen as an important financial priority for economic growth in the region. The fiscal potential should ensure the positive dynamics of the development of the territory and create a competitive environment.

The new modern model of society management, built in the context of the reform of the territorial organization of power, is based on the creation of financially self-sufficient communities. Local taxes and fees are one of the important sources of local government budget revenue generation. Starting from 2014, the share of local taxes and fees grows in the revenues of local budgets of Ukraine. Such changes are due to the improvement of tax and budgetary legislation, as well as the interest of local self-government bodies in additional mobilization of revenues to local budgets. Therefore, increasing the role of local taxes and fees, as well as increasing their share in local budgets' own revenues, is one of the main tasks of the fiscal policy of the state.

One of the innovations that will positively affect local budget revenues is the introduction of a land tax for forest land and the establishment of a tax rate per hectare of forest land. That is, local budgets are able to get additional resources through the taxation of forest lands. It is also assumed that the deduction of personal income tax for leased land should be carried out at the location of such facilities. Another new source of revenue generation for local government budgets is a $5 \%$ rent for the use of mineral resources for the extraction of minerals of national significance. The payment will be received at the place of extraction of minerals in full size.

Consequently, the establishment and collection of local taxes and duties is one of the effective mechanisms for the formation of the resource potential of local self-government bodies. The size of local taxes depends on the effective organization of work on their introduction and collection. In addition, it is important to effectively secure consolidated national taxes, such as personal income tax, excise and rent payments. Local governments have real opportunities to influence the volume of revenues from local tax payments to the respective budgets through the introduction and setting of the rates. Therefore, it is important and timely to create a resource and material base of local importance, as well as identify ways to increase its fiscal potential. This should positively affect the financial self-sufficiency of local budgets.

Keywords: local budget, budget capability, fiscal policy, local taxes and fees.

Постановка проблеми. Стратегічними орієнтирами підвищення конкурентоспроможності та фінансової самодостатності органів місцевого самоврядування в рамках сучасної політики розвитку держави та їі регіонів є подальше проведення децентралізації та реформування державного управління. В контексті останньої безсумнівно важливою парадигмою економічної політики держави у $2019-2021$ рp. $\epsilon$ продовження фіскальної консолідації; зокрема, впровадження ефективного врядування шляхом 
переформатування державних та місцевих фінансів, а також визначення середньострокової фіскальної бази. Першочерговим завданням органів місцевого самоврядування $є$ підвищення ролі фіскальних платежів місцевого значення та збільшення їх частки у власних доходах місцевих бюджетів, що, в свою чергу, сприятиме посиленню фінансової стійкості та самостійності адміністративнотериторіальних одиниць.

Аналіз останніх досліджень і публікацій. У вітчизняній економічній літературі над вивченням теоретичних аспектів формування доходної частини місцевих бюджетів за рахунок місцевих податків і зборів, а також пошуком шляхів їх реформування займались такі вчені, як О. Барановський, М. Бадида, О. Білянський, М. Вікторчук, Г. Возняк, Т. Городецька, Є. Качан, О. Кириленко, Л. Коваленко, В. Кравченко, О. Люта, П. Мельник, В. Опарін, О. Покатаєва, А. Стаценко, В. Теремецький, І. Чугунов, С. Юрій та багато інших.

Незважаючи на значний доробок науковців в сфері формування фіскального потенціалу місцевих бюджетів, залишаються актуальними проблеми підвищення ролі місцевих податків та зборів в якості інструмента формування власних доходів бюджетів регіонів.

Постановка завдання. Метою дослідження $є$ визначення ролі фіскальної складової місцевих бюджетів в контексті фінансової децентралізації.

Виклад основного матеріалу. Сталий розвиток держави та її регіонів в контексті фінансової децентралізації визначається бюджетним потенціалом окремої адміністративно-територіальної одиниці (області, району, міста, села, селища), тобто обсягом власних і залучених фінансових ресурсів, акумульованих у місцевому бюджеті. Проголошена у 2014 р. автономія органів місцевого самоврядування має бути підкріплена відповідними правами щодо стягнення на власній території фіскальних платежів в обсягах, достатніх для задоволення потреб місцевого розвитку. Внутрішній фіскальний потенціал розглядається на сьогодні як важливий фінансовий пріоритет економічного росту регіону, який спроможний забезпечувати позитивну динаміку його розвитку й створювати конкурентне середовище.

Нова сучасна модель управління суспільством, що вибудовується в контексті реформування територіальної організації влади, грунтується на створенні фінансово самодостатніх громад. Починаючи уже з 2014 р., завдяки урядовим ініціативам, спостерігаємо значне покращення фінансової спроможності місцевих бюджетів. Загалом, протягом останніх чотирьох років власні доходи місцевих бюджетів України зросли на 124 млрд грн.

Так, за підсумками 2017 р. відбулось зростання частки власних доходів місцевих бюджетів у зведеному бюджеті України до $22 \%$, що на $5 \%$ більше порівняно з 2015 р. [2]. У цей період загальний розмір фінансових ресурсів, що $\epsilon$ у розпорядженні органів місцевого самоврядування, вперше перевищив половину від усього зведеного бюджету України та склав 51,2 \% [3].

Позитивним в даному напрямку є діяльність ОТГ, динаміка надходжень до бюджетів яких випереджає темпи зростання доходів по інших рівнях місцевих бюджетів. За інформацією фахівців 3 фінансової децентралізації Центрального офісу реформ при Мінрегіоні надходження власних доходів місцевих бюджетів 366 ОТГ за 2017 рік зросли на 87 \% та склали 9,3 млрд грн (приріст складає 4,3 млрд грн). А темп зростання власних доходів 159 ОТГ, які вже у 2016 р. отримували зарахування 60 \% ПДФО до своїх бюджетів, становить 34,2 \% (приріст - 1,1 млрд грн), що майже на $3 \%$ більше від середнього показника по Україні. В цілому, приріст надходжень податку 3 доходів фізичних осіб, який зараховується до місцевих бюджетів, склав 41,2 \%, що на 1,9 \% більше, ніж загалом по Україні [3].

Про фінансову спроможність місцевих бюджетів свідчать і залишки коштів, які склалися на рахунках станом на 1 січня 2018 року в розмірі 55,7 млрд грн.

За даними Міністерства регіонального розвитку, будівництва та ЖКГ у 2018 р. фактична сума власних доходів місцевих бюджетів України перевищила надходження за 2017 рік на $22 \%$ і склала 234 млрд грн. Зокрема, податку на доходи фізичних осіб надійшло 138,2 млрд грн, що більше від надходжень показника минулого року на 20,1 \%, а плати за землю - 27,3 млрд. грн, що майже на 3,6 \% більше порівняно 3 попереднім періодом. Фактичні надходження єдиного податку склали 29,5 млрд. грн (приріст - 6,2 млрд грн, або 26,5\%). Надходження акцизного податку з палива становлять 7,9 млрд. грн (ріст на 0,8 млрд. грн, або на 10,6 \%) [4]. В цілому приріст власних доходів місцевих бюджетів України порівняно з плановими показниками становить $1,3 \%$.

На 2019 рік тенденція до зростання також зберігається. Основними напрямки бюджетної політики на 2019-2021 роки, схваленими розпорядженням Кабінету Міністрів України від 18 квітня 2018 року № 315-р, Стратегією реформування системи управління державними фінансами на 2017- 
2020 роки, схваленої розпорядженням Кабінету Міністрів України від 08 лютого 2017 року № 142-р та відповідно до положень програми діяльності Міністерства фінансів України в напрямку децентралізації, передбачено поступове збільшення обсягу ресурсу місцевих бюджетів [5].

Так, фінансовий ресурс місцевих бюджетів на 2019 р. за прогнозними розрахунками становить 588,9 млрд. грн в тому числі: власні доходи місцевих бюджетів (із них реверсна дотація - 6,8 млрд. грн) складають - 291,1 млрд грн, що більше на 41,4 млрд. грн у порівнянні із затвердженими місцевими бюджетами на 2018 рік (приріст складає 16,6 \%), із них:

- загальний фонд становить 265,7 млрд. грн (збільшується на 38,4 млрд. грн або на 16,9 \% більше порівняно із затвердженими обсягами);

- спеціальний фонд - 25,5 млрд. грн (приріст становить 3,0 млрд. грн, що на 13,5 \% більше) [6].

Отже, 3 урахуванням реверсної дотації, яка перераховується місцевими бюджетами до державного бюджету, доходи місцевих бюджетів становитимуть 284,3 млрд. грн, у т. ч. загального фонду - 258,9 млрд. грн, що більше на 27 млрд. грн порівняно з прогнозним показником 2018 року (приріст становить $12 \%$ ) та на 24 млрд. грн більше порівняно з фактичним показником 2018 року (приріст становить $10 \%$ ) $[4,6]$.

Таким чином, зростання обсягу ресурсу місцевих бюджетів дотягатиметься шляхом підвищення податкоспроможності останніх.

Одним із важливих джерел формування власних доходів бюджетів органів місцевого самоврядування $\epsilon$ місцеві податки і збори. Конституцією України визначено, що органи місцевого самоврядування встановлюють місцеві податки та збори. У Законі України «Про місцеве самоврядування в Україні» від 21 травня 1997 року № 280/97-ВР (в редакції від 11 січня 2019 року) зазначено, що місцеві бюджети мають бути достатніми щодо здійснення органами місцевого самоврядування наданих їм законом повноважень для забезпечення мешканців відповідних громад якісними публічними послугами [1].

Враховуючи внесені зміни до податкового та бюджетного законодавства починаючи із 2014 p., a також зацікавленість та безпосередній вплив органів місцевого самоврядування на мобілізацію надходжень від місцевих податків і зборів, можемо чітко прослідкувати динаміку зростання їх питомої ваги в доходах місцевих бюджетів України (без трансфертів) за даними таблиці 1.

Таблиия 1

Склад та структура місцевих податків та зборів у доходах місцевих бюджетів України за 2012-2017 pp.*

\begin{tabular}{|c|c|c|c|c|c|c|}
\hline \multirow[b]{2}{*}{ Вид податкового надходження } & \multicolumn{6}{|c|}{ Рік } \\
\hline & 2012 & 2013 & 2014 & 2015 & 2016 & 2017 \\
\hline 1 & 2 & 3 & 4 & 5 & 6 & 7 \\
\hline \multicolumn{7}{|c|}{ Податкові надходження } \\
\hline Всього, млн грн & 85852,03 & 91191,07 & 87333,67 & 98218,36 & 146902,24 & 201005,13 \\
\hline \multicolumn{7}{|c|}{ Місцеві податки та збори } \\
\hline Всього, млн грн & 5455,03 & 7316,20 & 8055,15 & 27041,19 & 42261,50 & 52586,84 \\
\hline питома вага, \% & 7,15 & 8,65 & 9,68 & 27,53 & 28,77 & 26,16 \\
\hline \multicolumn{7}{|c|}{ в тому числі: } \\
\hline - податок на майно, млн грн & 0,09 & 22,54 & 44,88 & 16011,13 & 24989,36 & 29056,07 \\
\hline питома вага, \% & 0,00 & 0,31 & 0,56 & 59,21 & 59,13 & 55,25 \\
\hline - єдиний податок, млн грн & 4815,64 & 6640,52 & 7413,25 & 10975,09 & 17167,10 & 23388,29 \\
\hline питома вага, \% & 88,28 & 90,76 & 92,03 & 40,59 & 40,62 & 44,48 \\
\hline $\begin{array}{l}\text { - збір за місця для паркування } \\
\text { транспортних засобів, млл грн }\end{array}$ & 68,37 & 64,50 & 61,21 & 60,22 & 66,17 & 77,57 \\
\hline питома вага, \% & 1,25 & 0,88 & 0,76 & 0,22 & 0,16 & 0,15 \\
\hline - туристичний збір, млн грн & 38,39 & 41,69 & 24,77 & 37,13 & 54,09 & 70,23 \\
\hline питома вага, \% & 0,71 & 0,57 & 0,31 & 0,14 & 0,13 & 0,13 \\
\hline $\begin{array}{l}\text { - збір за провадження деяких видів } \\
\text { підприємницької діяльності } \\
\text { (до 1січня } 2015 \text { р.), млн грн }\end{array}$ & 532,54 & 546,95 & 511,05 & $-42,55$ & $-15,22$ & $-5,32$ \\
\hline питома вага, \% & 9,76 & 7,48 & 6,34 & $-0,16$ & $-0,04$ & $-0,01$ \\
\hline
\end{tabular}

*Складено автором на основі [8], [9], [10], [11], [12], [13]. 
Зважаючи на покращення стану мобілізації надходжень та зміну структури місцевих податків і зборів, їх частка у доходах місцевих бюджетів значно зросла впродовж останніх років. Якщо протягом 2007-2010 роках іх частка коливалася від 1,1\% до 1,4\%, то починаючи з 2011 року і до 2014 р. вона зросла до 8,8 \%, а в 2017 р. вже становила - 24,7 \% [2]. Найбільшу питому вагу у структурі місцевих податків і зборів займають надходження від плати за землю (50 \%) та єдиного податку (понад $44 \%$ ).

Отже, підвищення ролі місцевих податків і зборів та збільшення їх частки у власних доходах місцевих бюджетів є одним із головних завдань фінансово-бюджетної політики держави.

Починаючи 32019 року, одним із нововведень, що позитивно вплинуть на доходи місцевих бюджетів, є запровадження сплати земельного податку за лісові землі та встановлення ставки податку за один гектар лісових земель відповідно до статей 274 та 277 Податкового кодексу України. Тобто, місцеві бюджети мають змогу отримати додаткові ресурси за рахунок оподаткування лісових земель. Також передбачається, що зарахування податку на доходи фізичних осіб за здані в оренду (суборенду, емфітевзис) земельні ділянки, земельні частки (паї) повинно здійснюватися за місцезнаходженням таких об’ єктів. Іншим нововведенням є зарахування, починаючи з 1 січня 2019 р., $5 \%$ рентної плати за користування надрами для видобування корисних копалин загальнодержавного значення (крім рентної плати за користування надрами для видобування нафти, природного газу та газового конденсату) до бюджетів місцевого самоврядування за місцем видобутку відповідних корисних копалин (до 2019 року зарахування відбувалось у пропорціях: 25 \% - до обласних бюджетів, 75 \% до державного бюджету) [7].

Крім того, зберігається спрощена система оподаткування для платників податків єдиного податку I-IV груп, а також віднесення до четвертої групи (сільськогосподарські товаровиробники) фізичних осіб - підприємців, які провадять діяльність виключно в межах фермерського господарства; зберігається норма щодо зарахування 13,44 \% акцизного податку з пального до місцевих бюджетів (прогноз становить 7,4 млрд грн) [6].

Таким чином, місцеві податкові надходження є дієвим механізмом формування фінансового потенціалу місцевих бюджетів та джерелом соціально-економічного розвитку окремих територій громад.

Висновки. Отже, встановлення і стягнення місцевих податків та зборів $є$ одним із дієвих механізмів формування ресурсного потенціалу органів місцевого самоврядування, а також джерелом соціального та економічного розвитку територій громад. Розмір фіскальної складової місцевих бюджетів залежить від ефективної організації комплексу робіт із запровадження та збирання місцевих податків та зборів, а також із мобілізації закріплених податків, таких як ПДФО, акциз та рентні платежі. В контексті фінансової децентралізації органи місцевого самоврядування, в межах податкового законодавства та наданих їм компетенцій, мають реальні можливості впливати на обсяги надходжень місцевих податкових платежів до відповідних бюджетів через систему запровадження та встановлення розміру ставок. Тому, важливим і своєчасним є формування ресурсно-матеріальної бази місцевого значення, а також визначення шляхів підвищення ії фіскального потенціалу. Це, у свою чергу, повинно позитивно вплинути на фінансову самодостатність місцевих бюджетів.

\section{Джерела та література}

1. Закон України «Про місцеве самоврядування». URL: https://zakon.rada.gov.ua/laws/show/280/97-вp.

2. Місцеві податки і збори. URL: https://decentralization.gov.ua.

3. Власні доходи місцевих бюджетів України зросли на 124 мільярди. URL: https://www.ukrinform.ua/rubricregions.

4. Власні доходи місцевих бюджетів у 2018 році перевищили заплановані. URL: https://decentralization. gov.ua/news/10455.

5. Основні напрямки бюджетної політики на 2019-2021 роки. URL: http://w1.c1.rada.gov.ua/pls/zweb2/ webproc4_1?pf3511.

6. Що очікує місцеві бюджети у 2019 році. URL: https://decentralization.gov.ua/news/9753.

7. Мінфін визначив основні параметри формування місцевих бюджетів на 2019 рік. URL: https://uteka.ua.

8. Річний звіт станом на 1 січня 2013 року. URL: https://www.treasury.gov.ua/ua/file-storage/richniy-zvit.

9. Річний звіт станом на 1 січня 2014 року. URL: https://www.treasury.gov.ua/ua/file-storage/richniy-zvitstanom-na-01012014.

10. Річний звіт про виконання державного бюджету на 01.01.2015 року. URL: https://www.treasury. gov.ua/ua/file-storage/richna-zvitnist-5. 
11. Річний звіт про виконання Державного бюджету України за 2015 рік. URL: https://www.treasury.gov.ua/ ua/file-storage/richna-zvitnist-4.

12. Річний звіт про виконання Державного бюджету України за 2016 рік. URL: https://www.treasury.gov. ua/ua/file-storage/richna-zvitnist-3.

13. Річний звіт про виконання Державного бюджету України за 2017 рік. URL:: https://www.treasury.gov.ua/ ua/file-storage/richna-zvitnist-2.

\section{References}

1. Zakon Ukrajiny «Pro misceve samovrjaduvannja» [Law of Ukraine «On Local Self-Government»]. (n.d.). zakon.rada.gov.ua. Retrieved from https://zakon.rada.gov.ua/laws/show/280/97-вp [in Ukrainian].

2. Miscevi podatky i zbory [Local taxes and fees]. decentralization.gov.ua. Retrieved from https:// decentralization. gov.ua [in Ukrainian].

3. Vlasni dokhody miscevykh bjudzhetiv Ukrajiny zrosly na 124 miljjardy [Own revenues of local budgets of Ukraine increased by 124 billion]. ukrinform.ua. Retrieved from https://www.ukrinform.ua/rubric-regions [in Ukrainian].

4. Vlasni dokhody miscevykh bjudzhetiv u 2018 roci perevyshhyly zaplanovani [Local budgets' own revenues in 2018 exceeded the planned ones]. decentralization.gov.ua. Retrieved from https://decentralization.gov.ua/ news/10455 [in Ukrainian].

5. Osnovni naprjamky bjudzhetnoji polityky na 2019-2021 roky [The main directions of budget policy for 20192021 years]. w1.c1.rada.gov.ua. Retrieved from https://w1.c1.rada.gov.ua/pls/zweb2/webproc4_1?pf3511 [in Ukrainian].

6. Shho ochikuje miscevi bjudzhety u 2019 roci [What awaits local budgets in 2019]. decentralization.gov.ua. Retrieved from https://decentralization.gov.ua/news/9753 [in Ukrainian].

7. Minfin vyznachyv osnovni parametry formuvannja miscevykh bjudzhetiv na 2019 rik [The Ministry of Finance identified the main parameters for the formation of local budgets by 2019]. uteka.ua. Retrieved from https://uteka.ua [in Ukrainian].

8. Richnyj zvit stanom na 1 sichnja 2013 roku [Annual report as of January 1, 2013]. (n.d.). treasury.gov.ua. Retrieved from https://www.treasury.gov.ua/ua/file-storage/richniy-zvit [in Ukrainian].

9. Richnyj zvit stanom na 1 sichnja 2014 roku [Annual report as of January 1, 2014]. (n.d.). treasury.gov.ua. Retrieved from https://www.treasury.gov.ua/ua/file-storage/richniy-zvit-stanom-na-01012014 [in Ukrainian].

10. Richnyj zvit pro vykonannja derzhavnogho bjudzhetu na 01.01.2015 roku [Annual report on implementation of the state budget as of 01.01.2015]. (n.d.). treasury.gov.ua. Retrieved from https://www.treasury.gov.ua/ ua/file-storage/richna-zvitnist-5 [in Ukrainian].

11. Richnyj zvit pro vykonannja Derzhavnogho bjudzhetu Ukrajiny za 2015 rik [Annual report on implementation of the State Budget of Ukraine for 2015]. (n.d.). treasury.gov.ua. Retrieved from https://www.treasury.gov.ua/ ua/file-storage/richna-zvitnist-4 [in Ukrainian].

12. Richnyj zvit pro vykonannja Derzhavnogho bjudzhetu Ukrajiny za 2016 rik [Annual report on implementation of the State Budget of Ukraine for 2016]. (n.d.). treasury.gov.ua. Retrieved from https://www.treasury.gov.ua/ ua/file-storage/richna-zvitnist-3 [in Ukrainian].

13. Richnyj zvit pro vykonannja Derzhavnogho bjudzhetu Ukrajiny za 2017 rik [Annual report on implementation of the State Budget of Ukraine for 2017]. (n.d.). treasury.gov.ua. Retrieved from https://www.treasury.gov.ua/ ua/file-storage/richna-zvitnist-2 [in Ukrainian].

Стаття надійшла до редакції 29.12.2019 p. 